\title{
Prevalence of metabolic syndrome in Brazilian adults: a systematic review
}

Fernanda de Carvalho Vidigall ${ }^{1}$, Josefina Bressan ${ }^{1}$, Nancy Babio ${ }^{2,3}$ and Jordi Salas-Salvadó $2,3^{*}$

\begin{abstract}
Background: The metabolic syndrome (MS) is a complex of risk factors for cardiovascular disease. This syndrome increases the risk of diabetes, cardiovascular disease and all-cause mortality. It has been demonstrated that the prevalence of MS is increasing worldwide. Despite the importance of MS in the context of metabolic and cardiovascular disease, few studies have described the prevalence of MS and its determinants in Latin America. The present study aims to assess studies describing the prevalence of MS in Brazil in order to determine the global prevalence of the syndrome and its components.

Methods: Systematic review. Searches were carried out in PubMed and Scielo from the earliest available online indexing year through May 2013. There were no restrictions on language. The search terms used to describe MS were taken from the PubMed (MeSH) dictionary: "metabolic syndrome x", "prevalence" and "Brazil". Studies were included if they were cross-sectional, described the prevalence of MS and were conducted in apparently healthy subjects, from the general population, 19-64 years old (adult and middle aged) of both genders. The titles and abstracts of all the articles identified were screened for eligibility.

Results: Ten cross-sectional studies were selected. The weighted mean for general prevalence of MS in Brazil was 29.6\% (range: 14.9\%-65.3\%). Half of the studies used the criteria for clinical diagnosis of MS proposed by the National Cholesterol Education Program Adult Treatment Panel III (NCEP-ATP III) (2001). The highest prevalence of MS (65.3\%) was found in a study conducted in an indigenous population, whereas the lowest prevalence of MS (14.9\%) was reported in a rural area. The most frequent MS components were low HDL-cholesterol (59.3\%) and hypertension (52.5\%).
\end{abstract}

Conclusions: Despite methodological differences among the studies selected, our findings suggested a high prevalence of MS in the Brazilian adult population.

Keywords: Metabolic syndrome, Prevalence, Brazil

\section{Background}

The metabolic syndrome (MS) is a complex of interrelated risk factors for cardiovascular disease and diabetes. These factors include hyperglycemia, hypertension, high triacylglycerol levels, low HDL-cholesterol (HDL-c) levels, and abdominal obesity [1]. Separately the MS components increase the risk of diabetes, cardiovascular disease and all-cause mortality, but the full syndrome is associated

\footnotetext{
* Correspondence: jordi.salas@urv.cat

${ }^{2}$ Human Nutrition Unit, Department of Biochemistry and Biotechnology, University Hospital Sant Joan de Reus, IISPV, Faculty of Medicine and Health Sciences, Rovira i Virgili University, Reus, Spain

${ }^{3} \mathrm{ClBER}$ obn Physiopathology of Obesity and Nutrition, Institute of Health Carlos III, Madrid, Spain

Full list of author information is available at the end of the article
}

with risk increases that are greater than the sum of the risk of each feature [2]. It has been reported that the association of MS with cardiovascular disease increases total mortality 1.5 times and cardiovascular death 2.5 times [3]. People with MS also have a 5-fold higher risk of developing type 2 diabetes [4].

The underlying cause of MS continues to challenge the experts. However, insulin resistance and abdominal obesity are postulated to be the key components. Genetic predisposition, physical inactivity, smoking, an unhealthy dietary pattern, ageing, proinflammatory state and hormonal changes may also have a causal effect. Their role, however, may depend on ethnic group [3-5]. The origin 
of all those metabolic disorders can be explained by a proinflammatory state derived from excessive caloric intake and overnutrition, and, perhaps, other chronic inflammatory conditions. This hypothesis asserts that this proinflammatory state, being characterized by an increase in inflammatory mediators, induce insulin resistance and leads to oxidative stress, with the potential to impair several biological pathways inducing insulin resistance. Therefore, insulin resistance could act as the common link among all the components of MS [6].

It has been demonstrated that the prevalence of MS is increasing worldwide, and for the adult population is estimated to be about 20 to $25 \%$, largely the result of greater obesity and sedentary lifestyles [1,4]. In the United States of America, the prevalence of MS estimated in adults from the National Health and Nutrition Examination Survey (NHANES) decreased from $25.5 \%$ in $1999 / 2000$ to $22.9 \%$ in 2009/2010 [7]. Studies conducted in Latin American populations from Chile, Colombia, Mexico, Peru and Venezuela revealed a high prevalence of MS which ranged from $12.3 \%$ to $42.7 \%$ depending on the criteria for clinical diagnosis and the characteristics of the study population [8-12].

Despite of the importance of MS in the context of metabolic and cardiovascular disease, in Brazil, few studies have described the prevalence of MS and its determinants, hence restricting the quality of information available on the magnitude of this problem in the country. Therefore, to help provide a clearer picture of the current situation in Brazil, we aimed to systematically review the available epidemiological data on the prevalence of MS in the Brazilian adult population.

\section{Methods}

\section{Search strategy and eligibility criteria}

An electronic bibliographic index (PubMed) and a multidisciplinary database for Ibero-America (Scielo) were searched from the earliest available online indexing year through May 2013, with no language restrictions. The search terms used to describe MS were taken from the PubMed (MeSH) dictionary: "metabolic syndrome $\mathrm{x}$ " $\mathrm{MeSH}]$ AND "prevalence" [MeSH] AND "Brazil" [MeSH] refined by ages (adult: 19-44 years AND middle aged: 45-64) in "All Fields" as tag terms. The key words used in Scielo were the same as those used in PubMed $(\mathrm{MeSH})$ without filter restrictions.

Studies were included if they were cross-sectional, described the prevalence of MS and were conducted in Brazilian populations. We restricted this review to studies on healthy adults and/or on the general population. Studies were excluded if they were conducted in subjects with diseases, in pregnant women, in the elderly ( $\geq 65$ years) or in a specific population (Figure 1).

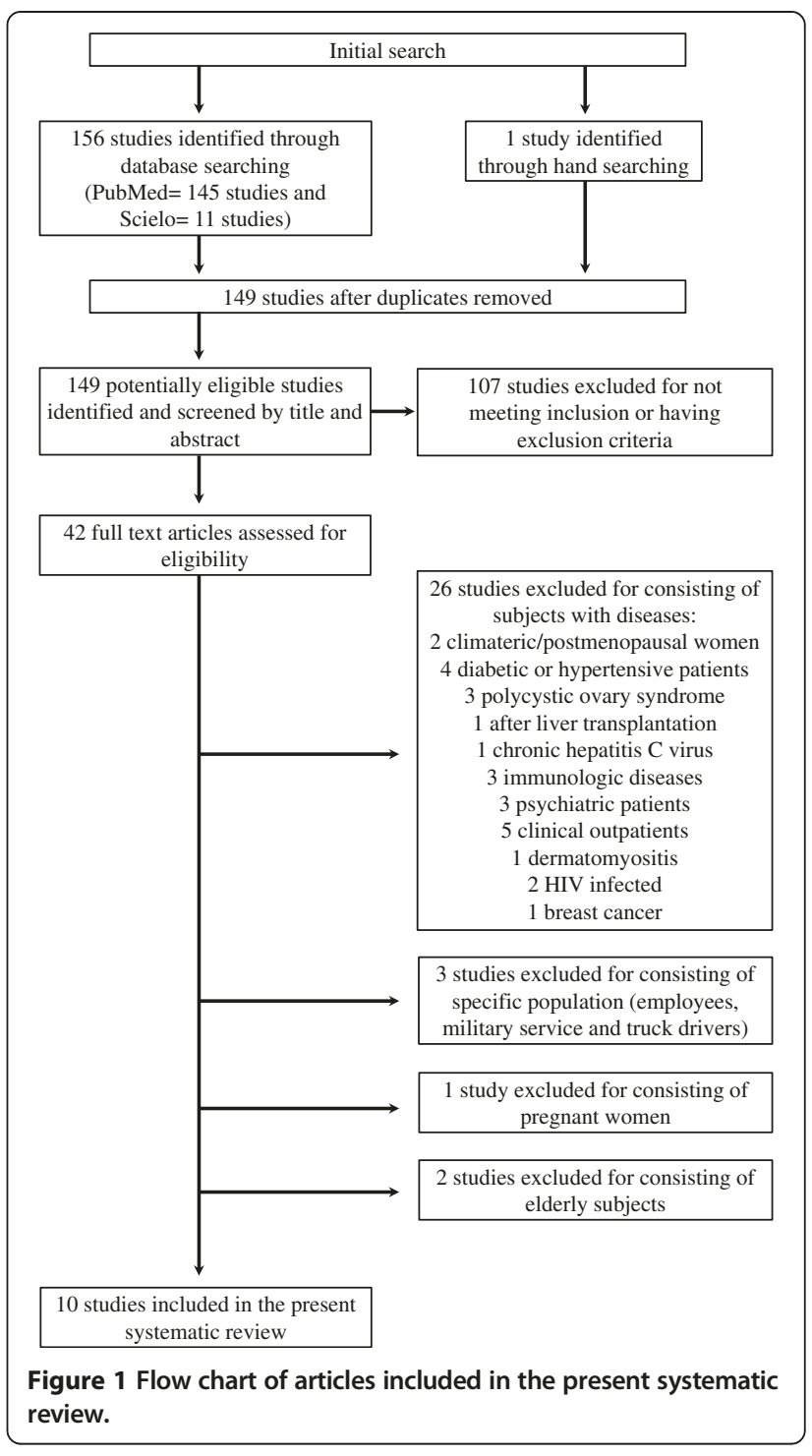

\section{Study selection and data extraction}

The title and abstracts of all the articles identified were screened for eligibility. All potentially relevant titles and abstracts were selected for full text examination. To be included in the review, a study had to: 1) be cross-sectional; 2) focus on MS prevalence; 3) examine a healthy population; 4) examine a general adult population (19 to 64 years old) of both sexes; 5) provide sufficient information to accomplish the objectives of the present systematic review. Although the focus of our review was the adult population, some of the articles selected included both adult and elderly subjects, and therefore some subjects were more than 65 years old.

A total of 156 studies containing data on the prevalence of MS in Brazil were automatically identified by applying the aforementioned search terms and 1 study was selected by hand searching. The selection processes for the articles are shown in Figure 1. 
Of the 145 studies identified in PubMed, 105 were excluded because they did not meet the inclusion criteria or had exclusion criteria. Of the 40 articles screened (titles and abstracts), 31 were excluded for the following reasons: 25 were conducted on subjects with diseases, 3 were carried out on specific populations, 1 comprised pregnant women and 2 consisted of elderly subjects. Therefore, 9 studies from this database were included in our systematic review.

Of the 11 studies identified by Scielo, 8 were excluded because they were duplicates, 2 did not meet the inclusion criteria or had exclusion criteria, and 1 was conducted on subjects with diseases. Therefore, no studies from this database were included.

One study was selected by hand searching, so a total of 10 studies were finally selected for the present systematic review.

Once the articles had been selected, the following significant data were extracted: authors and year of publication, study location (city, region), number of participants (W/M), age range, measurements, criteria for diagnosis of MS, overall prevalence of MS (\%), overall prevalence of individual components of MS (\%) and relevant findings/ associations.

\section{Outcome}

The weighted mean prevalence observed in the present systematic review was calculated as follows: sum of the number of cases in the studies considered $\div$ sum of the number of subjects in all studies considered $\times 100$ [13].

\section{Results of the studies reviewed}

We summarize the results of ten cross-sectional studies selected for the present systematic review (Table 1). The studies had been published in scientific journals with impact factors ranging from $0.4[14,15]$ to 5.509 [16].

The studies were conducted in several populations, and various criteria had been used to diagnose MS. Of the ten cross-sectional studies selected, five had been carried out in urban populations [5,15-18], 3 in rural populations $[14,19,20]$ and 2 in indigenous populations [21,22]. According to demographic census by 2010 [23], in Brazil the indigenous population was $817,963(0.43 \%)$ for a total population of $190,755,799$. Therefore, it was important to include the indigenous population in the present review since they are part of the Brazilian population. Five of the ten studies used the criteria for diagnosing MS proposed by the National Cholesterol Education Program Adult Treatment Panel III (NCEP-ATP III) (2001) $[5,16,19,20,22]$; two the criteria of the International Diabetes Federation (IDF) [15,21]; one the criteria of the NCEP-ATP III (2005) [14]; one the harmonized criteria of the IDF and American Heart Association/National Heart, Lung, and Blood Institute (AHA/NHLBI) [18]; and one study used both IDF and NCEP-ATP III (2005) criteria [17]. Five studies $[5,14,16,19,20]$ used a mercury sphygmomanometer; de Oliveira et al. [21] used an aneroid sphygmomanometer; whereas Dutra et al. [18] and Gronner et al. [17] used an automatic instrument $\left(\mathrm{OMRON}^{\circ}\right)$ for measuring blood pressure. The two remaining studies $[15,22]$ did not mention how blood pressure was measured. Nine studies reported the number of measurements carried out (two $[5,15,18,20,21]$ or three $[14,16,17,19]$ ). Seven studies mentioned the measurement site of blood pressure (right arm $[14,19,21,22]$, left arm [16,20] or nondominant arm [5]). Of the ten studies, eight measured the waist circumference at the midpoint between the iliac crest and the lowest rib [14-19,21,22]; one at the lower curvature between the lowest rib and the iliac crest [5]; and one at the umbilical level [20] (Table 1).

\section{Prevalence of metabolic syndrome in Brazil}

The studies selected [5,14-22] in this systematic review comprised 8,505 subjects, $60.8 \%$ of whom were women and $39.2 \%$ men. Nine studies had more women than men [5,15-22], whereas one had similar numbers $(50.6 \%$ men and $49.4 \%$ women) [14].

In nine studies, the general prevalence of MS (unadjusted for age and/or gender) was reported [5,14-16,18-22]. In two of these the prevalence was adjusted for age $[19,20]$, and in one it was adjusted for age and gender [15]. One study did not report the general prevalence and only described the prevalence adjusted for age and gender [17]. In the studies that mentioned rates of prevalence, the weighted mean for general prevalence of MS was $29.6 \%$ [5,14-16,18-22]. In the studies that mentioned rates of prevalence using the NCEP-ATP III (2001) criterion, the weighted mean for general prevalence of MS was $28.9 \%$ $[5,16,19,20,22]$. The weighted mean for age adjusted prevalence was $22 \%[19,20]$ and the weighted mean for age and gender adjusted prevalence was 41.3\% [15,17], using the NCEP-ATP III (2001) and the IDF criteria, respectively. The weighted mean for general prevalence of MS according to region was $29.8 \%, 20.1 \%$ and $41.5 \%$ in urban $[5,15,16,18]$, rural $[14,19,20]$, and indigenous $[21,22]$ populations, respectively. Taking into account that the indigenous population represents only $0.43 \%$ of the total Brazilian population, we calculated the weighted mean for general prevalence of MS excluding the studies [21,22] conducted in indigenous population. The weighted prevalence of MS without taking into account the indigenous population was $28.3 \%$, only $1.3 \%$ lower than those calculated using the indigenous population studies (29.6\%).

MS was most prevalent (65.3\%) in a study conducted in the indigenous population of Rio Grande do Sul, using the NCEP-ATP III (2001) criterion for diagnosing MS [22]. The lowest prevalence of MS (14.9\%) was reported in Virgem das Graças and Caju, a rural area in the 
Table 1 Characteristics of cross-sectional studies that evaluated the prevalence of metabolic syndrome in the Brazilian adult population

\begin{tabular}{|c|c|c|c|c|c|c|c|c|}
\hline $\begin{array}{l}\text { Authors and } \\
\text { publication } \\
\text { year (Ref. no.) }\end{array}$ & City, region & $\begin{array}{l}\text { Number of } \\
\text { participants } \\
(\mathrm{W}, \mathrm{M})\end{array}$ & $\begin{array}{l}\text { Age range } \\
\text { (years) }\end{array}$ & Measurements & $\begin{array}{l}\text { Criteria for } \\
\text { diagnosis } \\
\text { of MS }\end{array}$ & $\begin{array}{l}\text { Overall } \\
\text { prevalence } \\
\text { of MS (\%) }\end{array}$ & $\begin{array}{l}\text { Overall prevalence } \\
\text { of individual } \\
\text { components of } \\
\text { MS (\%) }\end{array}$ & Relevant findings/Associations* \\
\hline \multirow[t]{10}{*}{$\begin{array}{l}\text { Dutra et al., } \\
2012[18]\end{array}$} & \multirow[t]{10}{*}{ Brasília, Federal District } & \multirow{10}{*}{$\begin{array}{l}2130 \\
(72.5 \% \mathrm{~W} \\
27.5 \% \mathrm{M})\end{array}$} & \multirow[t]{10}{*}{$\geq 18$} & $\begin{array}{l}\text { WC: at the midpoint between the } \\
\text { iliac crest and the lowest rib }\end{array}$ & \multirow{10}{*}{$\begin{array}{l}\text { IDF and AHA/ } \\
\text { NHLBI } \\
\text { harmonized } \\
\text { criteria (2009) }\end{array}$} & \multirow[t]{10}{*}{32.0} & AO: N/A & $\begin{array}{l}\text { Logistic regression model adjusted } \\
\text { for age: }\end{array}$ \\
\hline & & & & \multirow[t]{9}{*}{$\begin{array}{l}\text { Fasting G, TAG and HDL-c } \\
\text { BP: two measurements }\end{array}$} & & & High G: N/A & $\begin{array}{l}\text { Age } 25-34 \text { years: female: } P R=2.06 \text {; } \\
95 \% \text { Cl 1.13-3.74; male: } P R=3.35 ; \\
95 \% \text { Cl 1.27-8.88 }\end{array}$ \\
\hline & & & & & & & HT: N/A & $\begin{array}{l}\text { Age } 35-44 \text { years: female: } P R=3.62 ; \\
95 \% \text { Cl 2.04-6.44; male: } P R=4.87 ; \\
95 \% \text { Cl 1.94-12.20 }\end{array}$ \\
\hline & & & & & & & High TAG: N/A & $\begin{array}{l}\text { Age } 45-54 \text { years: female: } P R=5.42 ; \\
95 \% \text { Cl 3.08-9.55; male: } P R=7.60 ; \\
95 \% \text { Cl 3.08-18.70 }\end{array}$ \\
\hline & & & & & & & Low HDL-C: N/A & $\begin{array}{l}\text { Age } 55-64 \text { years: female: } P R=6.57 ; \\
95 \% \text { Cl 3.74-11.55; male: } P R=8.95 ; \\
95 \% \text { Cl 3.64-22.00 }\end{array}$ \\
\hline & & & & & & & & $\begin{array}{l}\text { Age } \geq 65 \text { years: female: } P R=7.45 \\
95 \% \text { Cl } 4.23-13.11 \text {; male: } P R=7.89 ; \\
95 \% \text { Cl 3.14-19.80 }\end{array}$ \\
\hline & & & & & & & & $\begin{array}{l}\text { BMI } 25-29 \mathrm{~kg} / \mathrm{m}^{2} \text { : female: } \\
\text { PR }=4.29 ; 95 \% \text { Cl 3.21-5.75; male: } \\
\text { PR }=4.52 ; 95 \% \text { Cl 2.64-7.74 }\end{array}$ \\
\hline & & & & & & & & $\begin{array}{l}\mathrm{BMI} \geq 30 \mathrm{~kg} / \mathrm{m}^{2}: \text { female: } \mathrm{PR}=7.04 \\
95 \% \mathrm{Cl} \text { 5.32-9.31; male: } \mathrm{PR}=9.99 \\
95 \% \mathrm{Cl} \text { 5.92-16.90 }\end{array}$ \\
\hline & & & & & & & & $\begin{array}{l}\text { Schooling } 9-11 \text { years: female: } \\
\mathrm{PR}=0.78 ; 95 \% \mathrm{Cl} 0.64-0.96\end{array}$ \\
\hline & & & & & & & & $\begin{array}{l}\text { Schooling } \geq 12 \text { years: female: } \\
\mathrm{PR}=0.51 ; 95 \% \mathrm{Cl} 0.37-0.70\end{array}$ \\
\hline \multirow{5}{*}{$\begin{array}{l}\text { de Oliveira } \\
\text { et al., } 2011 \\
{[21]}\end{array}$} & \multirow{5}{*}{$\begin{array}{l}\text { Jaguapiru Indigenous } \\
\text { Village, Dourados, Mato } \\
\text { Grosso do Sul }\end{array}$} & \multirow{5}{*}{$\begin{array}{l}606 \\
(55.8 \% \mathrm{~W}, \\
44.2 \% \mathrm{M})\end{array}$} & \multirow[t]{5}{*}{$18-69$} & $\begin{array}{l}\text { WC: at the midpoint between the } \\
\text { iliac crest and the lowest rib }\end{array}$ & \multirow[t]{5}{*}{ IDF } & \multirow[t]{5}{*}{35.7} & AO: 60.9 & \multirow[t]{5}{*}{ N/A } \\
\hline & & & & Fasting G, TAG and HDL-C & & & High G: 11.4 & \\
\hline & & & & \multirow[t]{3}{*}{ BP: two measurements } & & & HT: 40.3 & \\
\hline & & & & & & & High TAG: N/A & \\
\hline & & & & & & & Low HDL-C: N/A & \\
\hline \multirow[t]{2}{*}{$\begin{array}{l}\text { Gronner et al., } \\
2011[17]\end{array}$} & \multirow[t]{2}{*}{ Southeastern region } & \multirow{2}{*}{$\begin{array}{l}1116 \\
(64.5 \% \mathrm{~W}, \\
35.5 \% \mathrm{M})\end{array}$} & \multirow[t]{2}{*}{$30-79$} & $\begin{array}{l}\text { WC: at the midpoint between the } \\
\text { iliac crest and the lowest rib }\end{array}$ & \multirow[t]{2}{*}{$\begin{array}{l}\text { NCEP-ATPIII } \\
\text { (2005) and IDF }\end{array}$} & $\begin{array}{l}\text { NCEP-ATPIII } \\
\text { (2005): } 35.9\end{array}$ & $\begin{array}{l}\text { AO (NCEP-ATPIII } \\
\text { 2005): } 56.2\end{array}$ & Logistic regression model: \\
\hline & & & & Fasting G, TAG and HDL-C & & IDF: 43.2 & AO (IDF): 72.6 & $\begin{array}{l}\text { Age } 40-49 \text { yearst: } O R=2.15 ; 95 \% \\
\text { Cl 1.47-3.16 }\end{array}$ \\
\hline
\end{tabular}


Table 1 Characteristics of cross-sectional studies that evaluated the prevalence of metabolic syndrome in the Brazilian adult population (Continued)

\begin{tabular}{|c|c|c|c|c|c|c|c|c|}
\hline & & & & BP: three measurements & & & High G: 13.3 & $\begin{array}{l}\text { Age } 50-59 \text { yearst: } O R=2.68 ; 95 \% \\
\text { Cl } 1.85-3.89\end{array}$ \\
\hline & & & & & & & HT: 59.2 & $\begin{array}{l}\text { Age 60-69 yearst: } O R=4.64 ; 95 \% \\
\text { Cl 3.06-7.04 }\end{array}$ \\
\hline & & & & & & & High TAG: 16.8 & $\begin{array}{l}\text { Age } 70-79 \text { yearst: } O R=4.77 ; 95 \% \\
\text { Cl 3.11-7.32 }\end{array}$ \\
\hline & & & & & & & Low HDL-c: 76.3 & $\begin{array}{l}\text { Skin color whiteł: } O R=1.65 ; 95 \% \\
\text { Cl 1.28-2.14 }\end{array}$ \\
\hline & & & & & & & & $\begin{array}{l}\text { Schooling fundamental } \S: \\
\mathrm{OR}=2.51 ; 95 \% \mathrm{Cl} 1.58-4.00\end{array}$ \\
\hline & & & & & & & & $\begin{array}{l}\mathrm{BMI} \geq 25 \mathrm{~kg} / \mathrm{m}^{2}: \mathrm{OR}=5.68 ; \\
95 \% \mathrm{Cl} 4.30-7.51\end{array}$ \\
\hline \multirow[t]{7}{*}{$\begin{array}{l}\text { Pimenta et al., } \\
2011[14]\end{array}$} & \multirow{7}{*}{$\begin{array}{l}\text { Virgem das Graças and } \\
\text { Caju, Jequitinhonha } \\
\text { Valley, Minas Gerais }\end{array}$} & \multirow{7}{*}{$\begin{array}{l}534 \\
(49.4 \% \mathrm{~W} \\
50.6 \% \mathrm{M})\end{array}$} & \multirow[t]{7}{*}{$\geq 18$} & $\begin{array}{l}\text { WC: at the midpoint between the } \\
\text { iliac crest and the lowest rib }\end{array}$ & \multirow[t]{7}{*}{$\begin{array}{l}\text { NCEP-ATPIII } \\
(2005)\end{array}$} & \multirow[t]{7}{*}{14.9} & AO: 11.6 & Poisson regression model: \\
\hline & & & & Fasting G, TAG and HDL-C & & & High G: 10.6 & Female: $\mathrm{PR}=2.20 ; 95 \% \mathrm{Cl} 1.33-3.62$ \\
\hline & & & & BP: three measurements & & & HT: 59.7 & $\begin{array}{l}\text { Obesity }\left(\mathrm{BMI} \geq 30 \mathrm{~kg} / \mathrm{m}^{2}\right): \\
\mathrm{PR}=3.03 ; 95 \% \mathrm{Cl} 2.05-4.48\end{array}$ \\
\hline & & & & & & & High TAG: 15.2 & $\begin{array}{l}\text { CRP } \geq 4^{\circ} \text { quartile: } P R=1.56 ; \\
95 \% \text { Cl 1.05-2.31 }\end{array}$ \\
\hline & & & & & & & Low HDL-C: 44.1 & $\begin{array}{l}\text { HOMA-IR } \geq 4^{\circ} \text { quartile: } P R=1.92 \\
95 \% \text { Cl 1.28-2.88 }\end{array}$ \\
\hline & & & & & & & & $\begin{array}{l}\text { Age } \geq 60 \text { yearst: } P R=7.06 ; C l 95 \% \\
\text { 2.62-19.04 }\end{array}$ \\
\hline & & & & & & & & $\begin{array}{l}\text { Alcohol consumption ( } 0.1 \text { to } 20 \mathrm{~g} \\
\text { ethanol/day): } \mathrm{PR}=0.26 ; \mathrm{Cl} 95 \% \\
0.09-0.73\end{array}$ \\
\hline \multirow{5}{*}{$\begin{array}{l}\text { da Rocha } \\
\text { et al., } 2011 \\
\text { [22] }\end{array}$} & \multirow{5}{*}{$\begin{array}{l}\text { Porto Alegre and } \\
\text { Planalto/ Nonoai, Rio } \\
\text { Grande do Sul }\end{array}$} & \multirow{5}{*}{$\begin{array}{l}150 \\
(55.3 \% \mathrm{~W} \\
44.7 \% \mathrm{M})\end{array}$} & \multirow[t]{5}{*}{$40-104$} & $\begin{array}{l}\text { WC: at the midpoint between the } \\
\text { iliac crest and the lowest rib }\end{array}$ & \multirow[t]{5}{*}{$\begin{array}{l}\text { NCEP-ATPIII } \\
(2001)\end{array}$} & \multirow[t]{5}{*}{65.3} & AO: 64.7 & \multirow[t]{5}{*}{ N/A } \\
\hline & & & & Fasting G, TAG and HDL-C & & & High G: 38.0 & \\
\hline & & & & BP: N/A & & & HT: 64.7 & \\
\hline & & & & & & & High TAG: 48.7 & \\
\hline & & & & & & & Low HDL-c: 67.3 & \\
\hline \multirow[t]{5}{*}{$\begin{array}{l}\text { Silva et al., } \\
2011[15]\end{array}$} & \multirow[t]{5}{*}{ São Paulo } & \multirow{5}{*}{$\begin{array}{l}287 \\
(74.6 \% \mathrm{~W} \\
25.4 \% \mathrm{M})\end{array}$} & \multirow[t]{5}{*}{$20-64$} & $\begin{array}{l}\text { WC: at the midpoint between the } \\
\text { iliac crest and the lowest rib }\end{array}$ & \multirow[t]{5}{*}{ IDF } & \multirow[t]{5}{*}{36.6} & AO: N/A & \multirow{5}{*}{$\begin{array}{l}\text { Short height adjusted for age and } \\
\text { gender: } \mathrm{OR}=1.25 ; 95 \% \mathrm{Cl} 1.12- \\
1.26\end{array}$} \\
\hline & & & & Fasting G, TAG and HDL-C & & & High G: N/A & \\
\hline & & & & BP: two measurements & & & HT: N/As & \\
\hline & & & & & & & High TAG: N/A & \\
\hline & & & & & & & Low HDL-C: N/A & \\
\hline
\end{tabular}


Table 1 Characteristics of cross-sectional studies that evaluated the prevalence of metabolic syndrome in the Brazilian adult population (Continued)

\begin{tabular}{|c|c|c|c|c|c|c|c|c|}
\hline \multirow{5}{*}{$\begin{array}{l}\text { Marquezine } \\
\text { et al., } 2008 \\
\text { [16] }\end{array}$} & \multirow[t]{5}{*}{ Vitória, Espírito Santo } & \multirow{5}{*}{$\begin{array}{l}1561 \\
(54.5 \% \mathrm{~W} \\
45.5 \% \mathrm{M})\end{array}$} & \multirow[t]{5}{*}{$25-64$} & $\begin{array}{l}\text { WC: at the midpoint between the } \\
\text { iliac crest and the lowest rib }\end{array}$ & \multirow[t]{5}{*}{$\begin{array}{l}\text { NCEP-ATPIII } \\
(2001)\end{array}$} & \multirow[t]{5}{*}{25.4} & AO: 16.3 & $\begin{array}{l}\text { Logistic regression model adjusted } \\
\text { for age in female: }\end{array}$ \\
\hline & & & & Fasting G, TAG and HDL-C & & & High G: 21.4 & \multirow[t]{4}{*}{ Low social class: $\mathrm{OR}=1.64$} \\
\hline & & & & BP: three measurements & & & HT: 46.6 & \\
\hline & & & & & & & High TAG: 30.9 & \\
\hline & & & & & & & Low HDL-c: 54.3 & \\
\hline \multirow[t]{5}{*}{$\begin{array}{l}\text { Salaroli et al., } \\
2007[5]\end{array}$} & \multirow[t]{5}{*}{ Vitória, Espírito Santo } & \multirow[t]{5}{*}{$\begin{array}{l}1630 \\
(54.4 \% \mathrm{~W} \\
45.6 \% \mathrm{M})\end{array}$} & \multirow[t]{5}{*}{$25-64$} & $\begin{array}{l}\text { WC: at the natural waist or the } \\
\text { lower curvature between the } \\
\text { lowest rib and the iliac crest }\end{array}$ & \multirow[t]{5}{*}{$\begin{array}{l}\text { NCEP-ATPIII } \\
(2001)\end{array}$} & \multirow[t]{5}{*}{29.8} & AO: N/A & \multirow[t]{5}{*}{ N/A } \\
\hline & & & & Fasting G, TAG and HDL-C & & & High G: N/A & \\
\hline & & & & BP: two measurements & & & $H T: N / A$ & \\
\hline & & & & & & & High TAG: N/A & \\
\hline & & & & & & & Low HDL-c: N/A & \\
\hline \multirow{5}{*}{$\begin{array}{l}\text { Velásquez- } \\
\text { Meléndez } \\
\text { et al., } 2007 \\
\text { [19] }\end{array}$} & \multirow{5}{*}{$\begin{array}{l}\text { Virgem das Graças, } \\
\text { Jequitinhonha Valley, } \\
\text { Minas Gerais }\end{array}$} & \multirow{5}{*}{$\begin{array}{l}251 \\
(53.4 \% \mathrm{~W} \\
46.6 \% \mathrm{M})\end{array}$} & \multirow[t]{5}{*}{$18-88$} & $\begin{array}{l}\text { WC: at the midpoint between the } \\
\text { iliac crest and the lowest rib }\end{array}$ & \multirow[t]{5}{*}{$\begin{array}{l}\text { NCEP-ATPIII } \\
(2001)\end{array}$} & \multirow[t]{5}{*}{21.6} & AO: 26.7 & $\begin{array}{l}\text { Logistic regression model adjusted } \\
\text { for BMI, age and schooling: }\end{array}$ \\
\hline & & & & Fasting G, TAG and HDL-C & & & High G: 6.0 & $\begin{array}{l}\mathrm{BMI} \geq 25 \mathrm{~kg} / \mathrm{m}^{2}: \mathrm{OR}=21.14 \\
95 \% \mathrm{Cl} 8.43-50.01\end{array}$ \\
\hline & & & & BP: three measurements & & & HT: 62.5 & $\begin{array}{l}\text { Age } 30-42 \text { yearst: } O R=3.15 \\
95 \% \text { Cl 1.08-9.18 }\end{array}$ \\
\hline & & & & & & & High TAG: 22.3 & $\begin{array}{l}\text { Age } 43-59 \text { yearst: } O R=5.18 ; \\
95 \% \text { Cl 1.38-19.41 }\end{array}$ \\
\hline & & & & & & & Low HDL-c: 37.1 & $\begin{array}{l}\text { Age } 60-88 \text { yearst: } \mathrm{OR}=17.58 \text {; } \\
95 \% \mathrm{Cl} 3.45-49.51\end{array}$ \\
\hline \multirow{5}{*}{$\begin{array}{l}\text { de Oliveira } \\
\text { et al., } 2006 \\
\text { [20] }\end{array}$} & \multirow[t]{5}{*}{ Cavunge, Bahia } & \multirow{5}{*}{$\begin{array}{l}240 \\
(57.5 \% \mathrm{~W} \\
42.5 \% \mathrm{M})\end{array}$} & \multirow[t]{5}{*}{$25-87$} & WC: at the umbilical level & \multirow[t]{5}{*}{$\begin{array}{l}\text { NCEP-ATPIII } \\
(2001)\end{array}$} & \multirow[t]{5}{*}{30.0} & AO: 31.7 & $\begin{array}{l}\text { Age } \geq 45 \text { years: } P R=2.60 ; 95 \% \mathrm{Cl} \\
1.61-4.21\end{array}$ \\
\hline & & & & Fasting G, TAG and HDL-C & & & High G: 15.8 & \multirow{4}{*}{$\begin{array}{l}\text { Age } \geq 55 \text { years: } P R=3.00 ; 95 \% \mathrm{Cl} \\
1.84-4.89\end{array}$} \\
\hline & & & & BP: two measurements & & & HT: 57.1 & \\
\hline & & & & & & & High TAG: 19.6 & \\
\hline & & & & & & & Low HDL-c: 70.4 & \\
\hline
\end{tabular}

Abbreviations: AHA/NHLBI, American Heart Association/National Heart, Lung, and Blood Institute; AO, abdominal obesity; BP, blood pressure; BMI, body mass index; CRP, C-reactive protein; G, glucose; HDL-C,
HDL-cholesterol; high G, hyperglycemia; high TAG, hypertriglyceridemia; HOMA-IR, Homeostasis Model Assessment of Insulin Resistance; HT, hypertension; IDF, International Diabetes Federation; M, men; MS, metabolic syndrome; N/A, information not available; NCEP-ATP III, National Cholesterol Education Program Adult Treatment Panel III; PR, prevalence ratio; TAG, triacylglycerol; W, women; WC, waist circumference.

*Only statistically significant associations are shown $(P<0.05)$

tReference group for age $<30$ years.

‡Reference group for non-white skin color.

§Reference group for higher educational level. 
Jequitinhonha Valley (Minas Gerais), using the NCEP-ATP III (2005) criterion [14].

Nine studies reported the prevalence of MS by gender [5,14,16-22]. In five studies [14,19-22] the prevalence of MS was higher in women than in men. In four other studies [5,16-18] no difference was observed in the prevalence of MS between genders. The difference in prevalence between genders ranged between $0.2 \%$ [17] and $44.7 \%$ [22].

Nine studies reported the prevalence of MS by age $[5,14,16-22]$. In seven of these [5,14,16-20], the prevalence of MS increased with age, whereas in the other two $[21,22]$ this was not demonstrated. The prevalence of MS was highest verified in subjects more than 50 years old. In contrast, prevalence was generally lowest in those under 30, with the exception of the indigenous population of Mato Grosso do Sul where the lowest prevalence $(9.6 \%)$ was observed in subjects between 60 and $69[21]$.

\section{Prevalence of the metabolic syndrome components} The prevalence of the individual components of MS among the Brazilian population varied considerably between studies (Table 1). In six studies [14,16,17,19,20,22], the overall prevalence of individual components of MS was reported, whereas de Oliveira et al. [21] reported only the prevalence of abdominal obesity, hyperglycemia and hypertension. The overall weighted mean prevalence (range) by component was as follows: abdominal obesity $38.9 \%$ (11.6\%[14] $-72.6 \%[17])$; hyperglycemia $16 \%$ (6\%[19]-38\%[22]); hypertension 52.5\% (40.3\%[21]64.7\%[22]); hypertriglyceridemia $24 \%$ (15.2\%[14]-48.7\% [22]); low HDL-c 59.3\% (37.1\%[19]-76.3\%[17]).

The prevalence of individual components of MS by gender was reported in three studies [14,19,21]. In addition, three other studies described the prevalence of MS components by age and gender group $[16,17,20]$. In general, the prevalence of abdominal obesity and low HDL-c was higher in females, whereas prevalence of hypertension was higher in males. Generally, the prevalence of the individual components was higher in subjects more than 45 years old, except for the low HDL-c component.

\section{Abdominal obesity}

Seven studies reported the prevalence of abdominal obesity $[14,16,17,19-22]$. In these seven studies, the weighted mean prevalence of abdominal obesity was $38.9 \%$. The highest prevalence of abdominal obesity (72.6\%) was found in the urban population of São Paulo using the IDF criterion [17], whereas the lowest prevalence $(11.6 \%)$ was observed in the rural population of Minas Gerais using the NCEP-ATP III (2005) criterion [14].

\section{Hyperglycemia}

The prevalence of hyperglycemia was mentioned in seven studies $[14,16,17,19-22]$. The weighted mean prevalence of hyperglycemia was $16 \%$. The prevalence (38\%) was highest in the indigenous population of Rio Grande do Sul [22], and lowest (6\%) in the rural population of Minas Gerais [19]. Both studies used the NCEP-ATP III (2001) criteria.

\section{Hypertension}

The prevalence of hypertension was reported in seven studies $[14,16,17,19-22]$. The weighted mean prevalence of hypertension was $52.5 \%$. Hypertension was shown to be the most prevalent $(64.7 \%)$ in the indigenous population of Rio Grande do Sul [22]. The prevalence (40.3\%) was lowest in the indigenous population of Mato Grosso do Sul [21].

\section{Hypertriglyceridemia}

The weighted mean prevalence of hypertriglyceridemia was $24 \%$ in six studies $[14,16,17,19,20,22]$. Hypertriglyceridemia was most prevalent (48.7\%) among the indigenous population of Rio Grande do Sul [22], and least prevalent (15.2\%) in the rural population of Minas Gerais [14].

\section{Low HDL-cholesterol}

Six studies reported the prevalence of the low HDL-c component of the MS $[14,16,17,19,20,22]$. The weighted mean prevalence of low HDL-c was 59.3\%. The highest prevalence of this component was $76.3 \%$ in the urban population of São Paulo [17], and the lowest (37.1\%) was found in the rural population of Minas Gerais [19].

\section{Factors associated with metabolic syndrome}

The risk of MS increased significantly with age, body mass index (BMI) and such conditions as having a white skin color (compared with a non-white skin color), being female, belonging to a low social class, and belonging to the highest quartiles of C-reactive protein and Homeostasis Model Assessment of Insulin Resistance levels (Table 1). The strongest association was found with BMI $\geq 25 \mathrm{~kg} / \mathrm{m}^{2}$ (OR $=21.14 ; 95 \%$ CI 8.43-50.01) [19], followed by age with subjects aged between 60 and 88 years old compared with those under 30 (OR = 17.58; 95\% CI 3.45-49.51) [19].

Two studies reported factors that protected against the risk of MS. The education level in females [18], and moderate alcohol consumption ( 0.1 to $20 \mathrm{~g}$ ethanol/day) in males and females [14] were inversely related to MS prevalence.

\section{Discussion}

The present systematic review provides data on the prevalence of MS in the Brazilian adult population. According to this review, the weighted mean for the general 
prevalence of MS was between 28.9 and 29.6\% according to the criteria used to define MS. This observed prevalence was slightly higher than the prevalence estimated around the world (between 20\% and 25\%) [4]. In fact, the mean prevalence of MS in Brazil was higher than that reported in such European countries as Portugal (27.6\%) [24], Spain (26.6\%) [25], France (25\% in males and $15.3 \%$ in females) [26] and Italy (28\% in males and $26 \%$ in females) [27]. It was also higher than in the United States of America (22.9\%) [7] and some Latin American countries: Mexico (26.6\%) [8] and Peru (18.1\%) [10]. This mean prevalence of MS was higher than that observed in the CARMELA study, conducted in seven Latin American countries, and with a prevalence ranging from $14 \%$ to $27 \%$ [28]. Prevalences similar to the one we reported in Brazil were found in Chile (29.5\%) [12] and North Africa (30\%) [29]. The mean prevalence we found in Brazil, however, was lower than that reported in Asia-China (33.9\%) [30], Turkey (36.6\%) [31], and Iran (30.1\% in males and 55\% in females) [32]-and some other Latin American countries: Colombia (34.8\%) [11] and Venezuela (35.3\%) [9].

The highest prevalence (65.3\%) of MS in Brazil was reported in the indigenous population [22]. Likewise, when analyzed by region (urban, rural and indigenous), the highest weighted mean for general prevalence of MS was found in the indigenous population $(41.5 \%)$ [21,22], which suggests that these individuals are at higher risk of cardiovascular disease and diabetes. Kuang-Yao Pan et al. [33] demonstrated that indigenous groups living in the northern Ecuadorian Amazon had a 30\% higher probability of mortality and a $62 \%$ higher incidence rate of all-cause morbidity than colonists. According to the First National Survey of Indigenous People's Health and Nutrition, non-pregnant women presented the following risk factors: overweight (30.3\%), obesity (15.8\%) and hypertension (13.2\%) [34].

It is evident that substantial socioeconomic and demographic changes have occurred in the Brazilian population over the past decades and the transition from a rural to an urban lifestyle has been associated with a deterioration in the metabolic profile because of adverse changes in lifestyle habits [19]. Observed disparities in health indicators underscore that basic healthcare and sanitation services are not yet as widely available in Brazil's indigenous communities as they are in the rest of the country [34].

In the present review, the most frequent MS component was low HDL-c (59.3\%). The same results were found in Venezuela (65.3\%) [9], Colombia (96.1\%) [11] and Peru (females $=60.9 \%$ ) [10]. In other studies, the most frequent MS component was abdominal obesity: United States of America (56.1\%) and Chile (41.1\%) [12]. In contrast, the least frequent MS component in Brazil was hyperglycemia (16\%). This was also the rarest MS component observed in studies conducted in Colombia (3.9\%) [11], the United
States of America (19.9\%) [7] and Peru (5\% in females and $5.4 \%$ in males) [10]. In the Chinese population, the least frequent MS component was low HDL-c (5\% in females and $12.9 \%$ in males) [30].

The general prevalence of MS in Brazil, according to this review, ranged from $14.9 \%$ [14] to $65.3 \%$ [22], the differences in MS prevalence being as high as $50.4 \%$. The differences were also notable in terms of the prevalence of MS components with the abdominal obesity component showing the highest difference (61\%). The study of MS has been hampered by the lack of consensus on its definition, the cutoff points used for its respective components, and how waist circumference and blood pressure should be determined. This has an impact on clinical practice and health policy [3]. Barbosa et al. [35] conducted a crosssectional study in a population subgroup of 1439 adults in the city of Salvador in Brazil, and showed that the cutoff points for waist circumference proposed by NCEP-ATP III [36] were inappropriate and underestimated the prevalence of MS in the population studied, particularly in men. Different cutoff points for the waist circumference and the measurement site of waist circumference make it difficult to compare studies. Our results showed that in most studies [14-19,21,22] waist circumference was measured at the midpoint between the iliac crest and the lowest rib. However, Salaroli et al. [5] took measurements at the natural waist or the lower curvature between the lowest rib and the iliac crest, and de Oliveira et al. [20] at the umbilical level. Moreover, different techniques and instruments were also used to measure blood pressure. Another factor that limits the comparability between studies is the different source and type of population studied. For instance, five of the studies selected were conducted in urban populations [5,15-18], three in rural populations $[14,19,20]$ and two in indigenous populations [21,22]. Nevertheless, we selected only studies that evaluated apparently healthy adults from the general population in order to make it possible to compare studies, despite the variability in the populations studied. Nine studies had more women than men [5,15-22], whereas one had similar numbers of men and women [14].

In order to diagnose MS, half of studies [5,16,19,20,22] used the NCEP-ATP III (2001) criterion. There is no consensus about the best criterion for diagnosing MS in clinical practice. Recently, IDF and AHA/NHLBI representatives have held discussions in an attempt to resolve the remaining differences between MS definitions and they have recognised that the risk associated with a particular waist circumference measurement will depend on the population. The harmonized criterion proposed by IDF and AHA/NHLBI will enable countries to be compared in the future and should be used as a unifying worldwide consensus definition for MS [1]. Apart from the methodological differences between studies, the 
variability in the prevalence of MS observed in our review between populations could be explained by demographic, epidemiological and nutritional transitions, as well as environmental and social influences, and ethnic differences [18].

Like other reviews, this study has some limitations, so its findings should be interpreted with caution. The multicultural characteristics and the demographic and epidemiological variability in the Brazilian population make it difficult to generalize the findings of this study in Brazil. Further limitations are the different criteria used to diagnose MS, the different measurement sites and cutoff points for waist circumference and the cutoff points for hyperglycemia. Hence, the need for more specific and structured research on the prevalence of MS and its determinants in Brazil are imperative.

\section{Conclusions}

To our knowledge, this is the first published systematic review assessing studies on the prevalence of MS and its determinants in the Brazilian adult population. Despite the methodological differences and the lack of consensus on criteria for MS diagnosis, our systematic review indicates a high prevalence of MS in the healthy Brazilian adult population. Criteria for MS diagnosis need to be standardized and suitable cutoff points for individual MS components in Brazil defined if the precise scope of this public health problem in Brazil is to be determined. Information about how the clinical MS components are distributed and how they are related could provide greater insight into MS and contribute to the planning and implementation of public health strategies. Therefore, primary preventive care could be used to reduce its prevalence and impact on human health.

\section{Abbreviations \\ AHA/NHLBI: American Heart Association/National Heart, Lung, and Blood Institute; BMI: Body mass index; HDL-C: HDL-cholesterol; IDF: International Diabetes Federation; MS: Metabolic syndrome; NCEP-ATP III: National Cholesterol Education Program Adult Treatment Panel III; NHANES: National Health and Nutrition Examination Survey.}

\section{Competing interests}

The authors declare that they have no competing interests.

\section{Authors' contributions}

JB and JSS directed the present study. All the authors contributed to the study concept and design. FCV helped with article searches, review and selection. All the authors contributed to the analysis and interpretation of data and drafting of the manuscript. JSS and NB worked as methodological advisors. All authors read and approved the final manuscript.

\section{Acknowledgements}

We thank the CAPES Foundation, Ministry of Education of Brazil (Brasilia-DF 70040-020, Brazil) for providing FCV with a research grant (process $n^{\circ}$ 3928-13-6) and the CNPq Foundation, Brazil, for financial support. This study was funded, in part, by the Spanish Ministry of Health (ISCIII), PI1001407, Thematic Network G03/140, RD06/0045, FEDER (Fondo Europeo de Desarrollo Regional), and the Centre Català de la Nutrició de I'Institut d'Estudis Catalans. None of the funding sources played a role in the design, collection, analysis or interpretation of the data or in the decision to submit the manuscript for publication. The authors would like to thank the professors of the Federal University of Viçosa Luciana Ferreira da Rocha Sant'Ana and Silvia Eloiza Priore for their collaboration and RIBESMET (Red Iberoamericana para el Estudio del Síndrome Metabólico, http://www.ribesmet.org/) Thematic Network. Ethical approval not required.

\section{Author details}

${ }^{1}$ Postgraduate Program in Nutrition Science, Department of Nutrition and Health, Federal University of Viçosa, Viçosa, Brazil. ${ }^{2}$ Human Nutrition Unit, Department of Biochemistry and Biotechnology, University Hospital Sant Joan de Reus, IISPV, Faculty of Medicine and Health Sciences, Rovira i Virgili University, Reus, Spain. ${ }^{3}$ CIBERobn Physiopathology of Obesity and Nutrition, Institute of Health Carlos III, Madrid, Spain.

Received: 10 September 2013 Accepted: 11 December 2013

Published: 18 December 2013

\section{References}

1. Alberti KGMM, Eckel RH, Grundy SM, Zimmet PZ, Cleeman JI, Donato KA, Fruchart J-C, James WPT, Loria CM, Smith SC: Harmonizing the metabolic syndrome: a joint interim statement of the international diabetes federation task force on epidemiology and prevention; national heart, lung, and blood institute; american heart association; world heart federation; international atherosclerosis society; and international association for the study of obesity. Circulation 2009, 120(16):1640-1645.

2. Gami AS, Witt BJ, Howard DE, Erwin PJ, Gami LA, Somers VK, Montori VM: Metabolic syndrome and risk of incident cardiovascular events and death: a systematic review and meta-analysis of longitudinal studies. J Am Coll Cardiol 2007, 49(4):403-414.

3. Sociedade Brasileira de Hipertensão, Sociedade Brasileira de Cardiologia, Sociedade Brasileira de Endocrinologia e Metabologia, Sociedade Brasileira de Diabetes, Sociedade Brasileira de Estudos da Obesidade: I Diretriz brasileira de diagnóstico e tratamento da síndrome metabólica. Arq Bras Cardiol 2005, 84:3-28.

4. International diabetes federation, the IDF consensus worldwide definition of the metabolic syndrome. http://www.idf.org/webdata/docs/ IDF_Meta_def_final.pdf.

5. Salaroli LB, Barbosa GC, Mill JG, Molina MCB: Prevalência de síndrome metabólica em estudo de base populacional, Vitória, ES-Brasil. Arq Bras Endocrinol Metabol 2007, 51(7):1143-1152.

6. Bullon P, Morillo JM, Ramirez-Tortosa MC, Quiles JL, Newman HN, Battino M: Metabolic syndrome and periodontitis: is oxidative stress a common link? J Dent Res 2009, 88(6):503-518.

7. Beltrán-Sánchez H, Harhay MO, Harhay MM, McElligott S: Prevalence and trends of metabolic syndrome in the adult US population, 1999-2010. J Am Coll Cardiol 2013, 62(8):697-703.

8. Aguilar-Salinas CA, Rojas R, Gómez-Pérez FJ, Valles V, Ríos-Torres JM, Franco A, Olaiz G, Rull JA, Sepúlveda J: High prevalence of metabolic syndrome in Mexico. Arch Med Res 2004, 35(1):76-81.

9. Florez H, Silva E, Fernández V, Ryder E, Sulbarán T, Campos G, Calmón G, Clavel E, Castillo-Florez S, Goldberg R: Prevalence and risk factors associated with the metabolic syndrome and dyslipidemia in white, black, Amerindian and mixed hispanics in Zulia State, Venezuela. Diabetes Res Clin Pract 2005, 69(1):63-77.

10. Medina-Lezama J, Zea-Diaz H, Morey-Vargas OL, Bolaños-Salazar JF, MuñozAtahualpa E, Postigo-MacDowall M, Corrales-Medina F, Valdivia-Ascuña Z Cuba-Bustinza C, Paredes-Díaz S, et al: Prevalence of the metabolic syndrome in Peruvian Andean hispanics: the PREVENCION study. Diabetes Res Clin Pract 2007, 78(2):270-281.

11. Pinzón JB, Serrano NC, Díaz LA, Mantilla G, Velasco HM, Martínez LX, Millán PA, Acevedo SM, Moreno D: Impacto de las nuevas definiciones en la prevalencia del síndrome metabólico en una población adulta de Bucaramanga, Colombia. Biomedica 2007, 27(2):172-179.

12. Mujica V, Leiva E, Icaza G, Diaz N, Arredondo M, Moore-Carrasco R, Orrego R, Vasquez M, Palomo I: Evaluation of metabolic syndrome in adults of Talca City, Chile. Nutr J 2008, 7(1):14.

13. Márquez-Sandoval F, Macedo-Ojeda G, Viramontes-Horner D, Fernández Ballart JD, Salas Salvadó J, Vizmanos B: The prevalence of metabolic syndrome in Latin America: a systematic review. Public Health Nutr 2011, 14(10):1702-1713. 
14. Pimenta AM, Gazzinelli A, Velásquez-Meléndez G: Prevalência da síndrome metabólica e seus fatores associados em área rural de Minas Gerais (MG, Brasil). Cien Saude Colet 2011, 16(7):3297-3306.

15. Silva EC, Martins IS, Araújo EAC: Síndrome metabólica e baixa estatura em adultos da região metropolitana de São Paulo (SP, Brasil). Cien Saude Colet 2011, 16(2):663-668.

16. Marquezine GF, Oliveira CM, Pereira AC, Krieger JE, Mill JG: Metabolic syndrome determinants in an urban population from Brazil: Social class and gender-specific interaction. Int J Cardiol 2008, 129(2):259-265.

17. Gronner MF, Bosi PL, Carvalho AM, Casale G, Contrera D, Pereira MA, Diogo TM, Torquato MTCG, Souza GMD, Oishi J, et al: Prevalence of metabolic syndrome and its association with educational inequalities among Brazilian adults: a population-based study. Braz J Med Biol Res 2011, 44(7):713-719.

18. Dutra ES, de Carvalho KMB, Miyazaki E, Merchán-Hamann E, Ito MK: Metabolic syndrome in central Brazil: prevalence and correlates in the adult population. Diabetol Metab Syndr 2012, 4(1):1-9.

19. Velásquez-Meléndez G, Gazzinelli A, Côrrea-Oliveira R, Pimenta AM, Kac G: Prevalence of metabolic syndrome in a rural area of Brazil. Sao Paulo Med J 2007, 125(3):155-162

20. de Oliveira EP, de Souza MLA, de Lima MDA: Prevalência de síndrome metabólica em uma área rural do semi-árido baiano. Arq Bras Endocrinol Metabol 2006, 50(3):456-465.

21. de Oliveira GF, de Oliveira TR, Rodrigues FF, Corrêa LF, de Arruda TB, Casulari LA: Prevalence of metabolic syndrome in the indigenous population, aged 19 to 69 years, from Jaguapiru Village, Dourados (MS). Brazil. Ethn Dis 2011, 21(3):301-306.

22. da Rocha AKS, Bós AJG, Huttner E, Machado DC: Prevalence of metabolic syndrome in indigenous people over 40 years of age in Rio Grande do Sul, Brazil. Rev Panam Salud Publica 2011, 29(1):41-45.

23. IBGE, Censo Demográfico 1991/2010. http://indigenas.ibge.gov.br/graficose-tabelas-2?print=1\&tmpl=component.

24. Fonseca MJ, Gaio R, Lopes C, Santos AC: Association between dietary patterns and metabolic syndrome in a sample of Portuguese adults. Nutr J 2012, 11:64

25. Corbatón-Anchuelo A, Martínez-Larrad MT, Fernández-Pérez C, Vega-Quiroga S, Ibarra-Rueda JM, Serrano-Ríos M, For The Segovia Insulin Resistance Study Group M: Metabolic syndrome, adiponectin, and cardiovascular risk in Spain (The Segovia Study): impact of consensus societies criteria. Metab Syndr Relat Disord 2013, 11(5):309-318.

26. Wagner A, Dallongeville J, Haas B, Ruidavets JB, Amouyel P, Ferrières J, Simon C, Arveiler D: Sedentary behaviour, physical activity and dietary patterns are independently associated with the metabolic syndrome. Diabetes Metab 2012, 38(5):428-435.

27. Lacoviello L, Bonanni A, Costanzo S, Curtis A, Di Castelnuovo A, Olivieri M, Zito F, Donati MB, Gaetano G, the Moli-sani Project Investigators: The Moli-Sani project, a randomized, prospective cohort study in the Molise region in Italy; design, rationale and objectives. Ital J Public Health 2007, 4(2):110-118.

28. Escobedo J, Schargrodsky H, Champagne B, Silva H, Boissonnet C, Vinueza R, Torres M, Hernandez R, Wilson E: Prevalence of the metabolic syndrome in Latin America and its association with sub-clinical carotid atherosclerosis: the CARMELA cross sectional study. Cardiovasc Diabetol 2009, 8(1):52.

29. Belfki H, Ali SB, Aounallah-Skhiri H, Traissac P, Bougatef S, Maire B, Delpeuch F, Achour N, Ben Romdhane H: Prevalence and determinants of the metabolic syndrome among Tunisian adults: results of the transition and health impact in North Africa (TAHINA) project. Public Health Nutr 2012, 16(04):582-590.

30. Wang GR, Li L, Pan YH, Tian GD, Lin WL, Li Z, Chen ZY, Gong YL, Kikano G, Stange $K$, et al: Prevalence of metabolic syndrome among urban community residents in China. BMC Public Health 2013, 13(1):599.

31. Gundogan K, Bayram F, Gedik V, Kaya A, Karaman A, Demir O, Sabuncu T, Kocer D, Coskun R: Metabolic syndrome prevalence according to ATP III and IDF criteria and related factors in Turkish adults. Arch Med Sci 2013, 9(2):243-253.

32. Azimi-Nezhad M, Herbeth B, Siest G, Dadé S, Ndiaye NC, Esmaily H, Hosseini SJ, Ghayour-Mobarhan M, Visvikis-Siest S: High prevalence of metabolic syndrome in Iran in comparison with France: what are the components that explain this? Metab Syndr Relat Disord 2012, 10(3):181-188.
33. Kuang-Yao Pan W, Erlien C, Bilsborrow RE: Morbidity and mortality disparities among colonist and indigenous populations in the Ecuadorian Amazon. Soc Sci Med 2010, 70(3):401-411.

34. Coimbra CE Jr, Santos RV, Welch J, Cardoso AM, de Souza MC, Garnelo L, Rassi E, Foller M-L, Horta B: The first national survey of indigenous people's health and nutrition in Brazil: rationale, methodology, and overview of results. BMC Public Health 2013, 13(1):52.

35. Barbosa PJB, Lessa I, Almeida Filho N, Magalhães LBNC, Araújo J: Critério de obesidade central em população brasileira: impacto sobre a síndrome metabólica. Arq Bras Cardiol 2006, 87:407-414.

36. Grundy SM, Cleeman JI, Daniels SR, Donato KA, Eckel RH, Franklin BA, Gordon DJ, Krauss RM, Savage PJ, Smith SC, et al: Diagnosis and management of the metabolic syndrome: an American heart association/national heart, lung, and blood institute scientific statement. Circulation 2005, 112(17):2735-2752

doi:10.1186/1471-2458-13-1198

Cite this article as: de Carvalho Vidigal et al:: Prevalence of metabolic syndrome in Brazilian adults: a systematic review. BMC Public Health 2013 13:1198.

\section{Submit your next manuscript to BioMed Central and take full advantage of:}

- Convenient online submission

- Thorough peer review

- No space constraints or color figure charges

- Immediate publication on acceptance

- Inclusion in PubMed, CAS, Scopus and Google Scholar

- Research which is freely available for redistribution 